\title{
A unique approach to addressing brownfield sites
}

\author{
V. Pitruzzello \\ US Environmental Protection Agency, Region 2 - New York, USA
}

\begin{abstract}
The purpose of this paper is to describe the unique approach used by EPA Region 2 in providing expertise at the federal and state government levels to communities with brownfield sites. This approach can serve as a "model" for such programs elsewhere by illustrating how EPA Region 2's program has fostered and encouraged brownfields re-use by utilizing and combining various funding, administrative and technical resources available at the "state" and "national" level to address local brownfields issues. The U.S. Environmental Protection Agency's (EPA) Brownfields program began in 1993 with a small number of grants to municipalities. A report by the General Accountability Office estimated that there are nearly 450,000 brownfield sites in the United States. These grants were "pilots" at the time - the purpose of which was to test the process for getting brownfields identified, characterized, remediated and eventually redeveloped. In January 2001 the "Small Business Liability Relief and Brownfields Revitalization Act" was signed establishing the Brownfields legislation and moving the pilot/initiative program into a fully recognized self-standing program. Initial funding for the program had been $\$ 400,000$ and rose steadily during the pilot phase. With the enactment of legislation, the funding level rose to over $\$ 165$ million. Grants are provided to communities for the purpose of identifying brownfield sites and for site remediation. Funds are provided to states to develop state programs.
\end{abstract}

EPA Region 2 includes the States of New York and New Jersey, seven tribal nations, the Commonwealth of Puerto Rico and the U.S. Virgin Islands. The challenges to the Brownfields program are varied across the wide range of regional municipalities, from densely populated cities, to small hamlets, to tribal lands and to tropical communities. To address this variety, the Region 2 Brownfields program has developed a unique partnership with a number of Federal and State government agencies. We have formed an Interagency Workgroup (IAWG) that has over 40 partner agencies that bring member resources to assist individual communities. We have brought such assistance to over 140 communities. This presentation will illustrate some of the challenges and successes experienced by EPA Region 2 throughout this unique process and offer a model for brownfields programs throughout the world.

Keywords: brownfields, Environmental Protection Agency, Interagency Workgroup, hazardous waste sites, hazardous cleanup, redevelopment, United States. 


\section{Introduction}

Over the past several decades, the United States has undergone significant changes in its industrial and manufacturing economy. Businesses have changed locations moving to different geographic sections of the country and some industries have closed entirely. The result of this, in many cases, is hundreds of thousands of properties that were left contaminated or at least perceived to be contaminated. Many contamination problems associated with these blighted properties are being addressed by the U.S.E.P.A.'s brownfields program.

In addition to the stigma associated with such sites, brownfields has increased pressure on developing 'greenfields'. Developers became wary of tackling environmental problems, which could be expensive and potentially involve liability to the owners. Thus, commercial, industrial and residential developers opted for greenfields development, leaving brownfields vacant. In many cases, brownfield sites are located in the urban /inner city environment. Their vacant status left eyesores in the community and an overall negative impact on the community at large. Vacant tracts of land resulted in deleterious effects to "main street America" as businesses closed shop and moved on to non-contaminated areas. Urban areas suffered from decay and rural/suburban areas expanded with sprawling growth which was often unchecked or done in a haphazard fashion. The additional effect of air contamination from clogged rural roads became a reality and an unwanted result of suburban sprawl.

Local communities and some state governments realized early on that the issue needed to be addressed. They developed some creative funding programs and contamination cleanup programs to encourage cleanup and re-use of properties. However, it soon became apparent that there was a need for the Federal government to become a participant in addressing the overall problem of such contaminated sites. That role fell to EPA, which began their current Brownfields program in 1993 with a few grants designed to provide technical and funding assistance to "pilot communities".

The program has since expanded to over 1200 grants and funds are now provided for assessment and cleanup of sites. EPA also instituted a job training grant program, which provides funding for select local organizations to train a cadre of environmental technicians to conduct cleanup work. Many of these technicians work with environmental companies addressing sites local to their area (i.e. in their own "backyard"). There are currently over 90 job training grants.

The EPA brownfields program has resulted in leveraging over $\$ 8$ billion in cleanup and redevelopment funding and has helped create over 25,000 jobs associated with redevelopment.

\section{History and organization of region 2's brownfields Interagency Workgroup (IAWG)}

EPA Region 2 includes the States of New York and New Jersey, the Commonwealth of Puerto Rico and the Virgin Islands Territories. We realized 
early on that an effective brownfields program requires partnerships not only at the local level but also at the state and regional levels. This paper describes our Regional initiative to partner with local, state and federal agencies to address the brownfields problems within our area of jurisdiction. Through the IAWG, we have developed strong working relationships with many agencies to bring financial, administrative and technical assistance to brownfields communities.

\subsection{History of IAWG}

In 1998, EPA, at the national level, initiated a program known as "Showcase Communities". Through this program a partnership of federal agencies with interests in brownfields redevelopment was formed to offer special technical, financial and other assistance to selected communities. Brownfields Showcase Communities have three main goals: to promote environmental protection, economic redevelopment and community revitalization through the assessment, cleanup and sustainable re-use of brownfields; to link Federal, State, local and non-governmental action supporting community efforts to restore and re-use brownfields; and to develop national models demonstrating the positive results of public and private collaboration addressing brownfields challenges.

As a result of the Showcase Communities program, EPA 2 created the IAWG to marshal the resources available throughout the Federal and State governments in support of brownfields redevelopment. The initial focus of the IAWG was to support the two EPA 2 Brownfields Showcase Communities located in Glen Cove, New York and Trenton, New Jersey. The successes and partnerships developed through these initial actions were further expanded to other communities who received brownfields grants from the Federal government. To date, over 140 communities in Region II have experienced the benefits of working with the IAWG.

\subsection{Primary member agencies and summary role in IAWG process}

The primary federal and state agencies and organizations that participate in the IAWG process with EPA-2 are identified below

\subsubsection{Federal Government agencies}

- U.S. Department of Commerce Economic Development Administration (EDA)

The EDA's purpose is to generate new jobs; help retain existing jobs; and stimulate industrial and commercial growth in economically distressed areas

- Department of Defense: U.S. Army Corps of Engineers (USACE)

USACE investigates, designs, constructs, and maintains a variety of projects for national economic and environmental security.

- Department of Health and Human Services: Agency for Toxic Substances and Disease Registry (ATSDR) 
ATSDR was created by the Superfund legislation of 1980 to prevent or mitigate adverse human health effects and diminished quality of life resulting from exposure to hazardous substances in the environment.

- Department of Housing and Urban Development (HUD)

The Brownfields Redevelopment Initiative brings together different types of existing HUD assistance that communities can use to clean up and revitalize potentially contaminated sites.

- Department of the Interior, National Park Service

The National Park Service enables states and local governments to establish park and recreation areas and adapt historic buildings for public use.

- Department of Transportation: Federal Highway Administration (FHWA)

The Federal Highway Administration's (FHWA) mission is to help fund the construction, reconstruction and improvement of Interstate highways and other roads on the federal-aid interstate, primary, secondary and urban systems.

- U.S. Environmental Protection Agency: Brownfields Program (EPA)

The goal of EPA's Brownfields Program is to empower localities to work with public and private stakeholders to develop locally appropriate approaches to prevent, assess, safely cleanup and sustainably re-use brownfields.

- General Services Administration (GSA)

GSA reviews and identifies underutilized federal properties through its Brownfields Redevelopment Initiative.

- Small Business Administration (SBA

The SBA's mission is to provide prospective, new or established persons in the small business community with financial, procurement, management and technical assistance.

\subsubsection{State of New Jersey agencies}

- New Jersey Department of Environmental Protection (NJDEP)

The New Jersey Department of Environmental Protection includes a variety of resources, incentives and programs administered by various state agencies in order to provide a comprehensive tool box to support private and public brownfields revitalization. It administers a voluntary cleanup program.

- New Jersey Department of Transportation (NJDOT)

The New Jersey Department of Transportation (NJDOT) is committed to advancing projects that enhance safety, renew the aging infrastructure and support new transportation opportunities.

- New Jersey Economic Development Authority (NJEDA)

The NJEDA is a self-supporting, independent state agency whose mission is to stimulate business development, job creation and community revitalization throughout the State.

- New Jersey Redevelopment Authority (NJRA)

The NJRA is a state financing authority committed to the redevelopment of urban New Jersey areas and is a comprehensive resource center that customizes project financing for redevelopment projects.

- New Jersey Environmental Infrastructure Trust

This trust provides financing for environmental infrastructure projects and open space acquisitions. 


\subsubsection{State of New York agencies}

- State of New York Department of Environmental Conservation (NYSDEC)

The New York State Department of Environmental Conservation has three main functions: natural resource management, environmental quality protection and the promotion of public health, safety and recreation. It administers a voluntary cleanup program.

- New York State Department of Health (NYSDOH)

NYSDOH oversees the Drinking Water State Revolving Fund, which provides financial incentives for public and private water system infrastructure improvement.

- New York State Department of Transportation (NYSDOT)

NYSDOT oversees the Industrial Access Program, which is designed to complement economic development projects where transportation access poses a problem. The Transportation and Community and System Preservation Program provides funding for surface transportation projects (such as access to brownfield sites).

- New York State Division of Housing and Community Renewal (NYSDHCR)

NYSDHCR administers the Housing Development Fund to provide loans to non-profits organizations for low income housing projects.

- Empire State Development (ESD)

ESD provides loans, loan guarantees and grants that can help companies reduce the costs of undertaking a job creation or retention project.

- $\quad$ New York State Environmental Facilities Corporation (NYSEFC)

NYSEFC administers the Clean Water Revolving Fund where applicants can obtain interest free short term or low interest long term loans for facilities that reduce or prevent water pollution. Water quality portions of brownfields projects generally are eligible for such financing.

- Governor's Office for Small Cities

The Federal Housing and Urban Development (HUD) community development block grant program provides annual grants to states and eligible cities and urban counties for community improvement. The New York State Small Cities program utilizes the federal grants provided to New York.

- New York State Office of Park Recreation and Historic Preservation

This office provides for the acquisition of permanent easement for land and water properties (recreational access). It also oversees a Historic Preservation Program for the acquisition and rehabilitation of historic properties.

- New York Department of State, Division of Coastal Resources and Waterfront Revitalization

The Division of Coastal Resources is responsible for administering New York State's Coastal Management Program while advancing economic development opportunities and protecting natural coastal resources.

\subsubsection{Puerto Rico and the U.S. Virgin Islands}

In addition to working with the above agencies and entities, EPA 2 has initiated a very aggressive campaign to bring IAWG resources to the Commonwealth of Puerto Rico and the Virgin Island Territories. To date, over 60 communities in 
these locales have met through the IAWG process. The key agencies for the Caribbean initiative are listed below:

- Puerto Rico Department of Health

- Puerto Rico Department of Agriculture

- Puerto Rico Department of Natural and Environmental Resources

- Puerto Rico Department of Transportation and Public Works - Highway Authority

- Puerto Rico Department of Housing

- Puerto Rico Environmental Quality Board

- Puerto Rico Office of the Commissioner for Municipal Affairs.

- Puerto Rico Economic Development Bank

- Puerto Rico Department of Recreation and Sports

- Puerto Rico Aqueduct and Sewers Authority (PRASA)

- Puerto Rico Industrial Development Company (PRIDCO)

- Puerto Rico Department of Labor

\section{IAWG process}

The IAWG process is straightforward:

- We inform communities which have received brownfields grants or have an interest in redeveloping brownfield sites that the IAWG is a standing group ready and able to assist them.

- Communities contact EPA expressing their interest in participating in the process.

- $\quad$ EPA then meets or has a teleconference with the community to discuss the issues of concern and to how the community can best prepare for and present to the IAWG the issues of concern. This ""prep" approach came though a trial and error process from our initial meetings. It greatly assists the community to focus their needs rather than present a general review of their community.

- Communities are strongly encouraged to identify and request participation of local agencies (such as environmental department, health department, economic development, etc.). This helps develop strong ties with "sister" agencies at the state and federal levels.

- The IAWG meetings typically cover 3-4 community presentations over the course of a day. Whenever possible the IAWG meetings are held in a location close to the communities. This allows participating members to get a better sense of the affected community needs. All communities who present are strongly encouraged to attend the full day session to hear and learn from their co-presenting communities. Often, community needs are somewhat similar and so "lessons learned" is an excellent way to illustrate practical approaches to problem solving. What works in one community often will work in another.

- All meetings are facilitated by an independent non-government entity. This results in greater participation by both the community and the member 
agencies since the facilitator can quickly identify or expand upon community needs and draw in the resources to address the issue.

- Minutes are provided after the meetings to capture the issues, highlight follow up actions needed and identify the agency responsible for the follow up. Communities often receive financial assistance (in the form of competitive grants or low interest loans), technical assistance (engineering suggestions for assessing or cleaning up a brownfields site) and administrative assistance (such as expediting a permit or making contact with an appropriate agency person that can assist in resolving the issue).

\subsection{Success stories}

A number of redevelopment projects have been accomplished as a result of the coordination among the various Federal and State agencies. A few examples are provided below.

Trenton, New Jersey has been very aggressive in its use of the IAWG in support of its redevelopment projects. The Crane site was a former cook pottery company in the 1800s/early 1900s. The city acquired the property and used an EPA Brownfields grant to assess the site's environmental conditions. It then used funds provided by the NJ Department of Environmental Protection to remediate the site. Lastly, funds from the Urban Enterprise Zone (a HUD funded program) were utilized to convert the property to a commercial park. The Magic Marker site was a former battery manufacturing facility and later a felt pen (marker) production site. The city used an EPA grant to assess the site and then an EPA revolving loan fund grant for site remediation. Funds were also accessed from the NJ Economic Development Administration and the NJ DEP Watershed grant. The site will eventually be developed for affordable housing units and a contaminated drainage problem will be addressed to allow for public open space. In Kearny, New Jersey a former tool and dye manufacturing site was converted into a much needed local playground. Funds were provided by the EPA (assessment grant), NJ Economic Development Administration and HUD's Community Block Grant program.

In New York, the City of Glen Cove is undertaking a massive redevelopment of its waterfront district. The area was home to many industries including leather belting, tinwear manufacturing, tungsten ore refining and photographic film manufacturing. The planned future uses include a marina, ferry terminal, hotel, conference center, residential units and a pedestrian/cycle esplanade. Funding has been derived from five federal agencies, seven state agencies and seven local government entities. In addition, 11 local area agencies/businesses have provided funding or technical assistance for the project. In Yonkers, New York, the city used funding or technical assistance from the EPA and HUD, New York State Department of Environmental Conservation, the New York State Department of Health and local city and private sector entities to convert a former manufactured gas plant into the location for a new bakery, parking and green space. The bakery hired a number of local residents for its operation.

Through the IAWG efforts in Puerto Rico, the US Department of Agriculture - Rural Development was able to provide funding to the municipality of Aguas 
Buenas to rehabilitate an abandoned building into a youth center. HUD worked with the Municipality of Carolina on an affordable housing project for low income families. The Small Business administration provided technical assistance to the Municipality of Jayuya on ways to enhance business improvements (new hotel, restaurants and a panoramic cable car attraction).

\section{Conclusions}

These examples illustrate that through partnerships with and between communities, government agencies at the local, state and federal level it is possible to marshal the critical resources from diverse sources to successfully address the financial, technical, legal, and environmental challenges posed by brownfield sites. The IWAG process has provided an essential vehicle to facilitate such partnering, communications and cooperation among all three levels of government and other major brownfield stakeholders.

\section{References}

[1] New York State Department of Environmental Conservation-Brownfields Financial Resources Manual, Albany NY, 2003

[2] Hudson County Economic Development Corporation (New Jersey)

[3] Hudson County, NJ, November 2007

[4] City of Trenton, New Jersey, November 2007

[5] The United States Brownfields Program-Sven-Eric Kaiser, USEPA, Washington, DC, 2005

[6] United States Environmental Protection Agency, Office of Brownfields Cleanup and Redevelopment 